\title{
Refrigerator Coupling to a Water-Heater and Heating Floor to Save Energy and to Reduce Carbon Emissions
}

\author{
Romdhane Ben Slama \\ ISSAT Gabes Rue Omar Ibn Khattab, Gabes, Tunisia \\ Email: romdhaneb.slama@gmail.fr
}

Received August 24, 2012; revised September 28, 2012; accepted October 15, 2012

\begin{abstract}
With an aim of rationing use of energy, energy safety, and to reduce carbon emission, our interest was geared towards the refrigerators and all the refrigerating machines. Indeed the heat yielded by the exchanger condenser can be developed for the water heating, floors heating etc. After an encouraging theoretical study, two prototypes were produced in order to validate the theoretical results. A first refrigerator was coupled with a water-heater and another with a heating floor. The water temperature reached, in one day, is of $60^{\circ} \mathrm{C}$; which makes it possible to predict better results with a continuously used refrigerator. In the same way for the heating floor coupled with the second refrigerator, the temperature reached high values because the surface is reduced; however for the heating floors the standard fixes the temperature between $28^{\circ} \mathrm{C}$ and $30^{\circ} \mathrm{C}$.
\end{abstract}

Keywords: Refrigerator; Recuperator; Heating Water; Heating Floor; Heat Pump

\section{Introduction}

Energy consumption in the world is significant and in continuous growth. It is fundamentally linked to the life level. It promotes the thermal comfort of the citizen, through the heating and cooling systems (air-conditioners, water-heaters, refrigerators... ). With the aim of saving energy and to reduce carbon emission, it is necessary to find some innovating solutions in this field and to create negawatts.

For this reason, we propose to recover the waste heat on the refrigerator condenser level, and this by two methods:

- The first method is to enhance the heat lost during condensation of Freon, and this, recovering it in a water cumulus to heat it and to use in the domestics or other needs.

- the second method consists in heating a floor to replace the traditional heating radiators.

Finally, the heat recovery system does not have any modification on the basic refrigeration cycle. The tests and experiments show the effectiveness of this heat recovery project [1-6].

\section{Bibliographical Study}

The publications evoking the use of heat pumps for water heating are relatively very few. Let us quote Grazini, Skrivan, Huang, Jie [7-10] which extracts heat from the ambient air like cold source of the heat pump. Figure 1 is given as an example.
Others authors use solar energy like evaporator such as Hawlader, Li, Chyng, Borges, Huang [11-16].

Among the few publication jointly using the condenser and the evaporator of a heat pump (or refrigerator), we even quote our work concerning a solar sea water still developed by our self, at the National School Engineers of Gabes, Tunisia [17-23].

Figure 2 shows our system of solar desalination provided with the heat pump.

The condenser (6) heats water to be evaporated and the evaporator (2) makes it possible to condense instantaneously the vapour and thus to form the condensate collected in the gutter (3).

For the principle of refrigerator operation (Figure 3), this system can be considered as an insulated cupboard whose interior temperature is lower than the ambient temperature. To obtain cold inside the refrigerator, heat is extracted with the air and food and then is rejected by the condenser in the kitchen.

\section{Theoretical Considerations of the Coupling of Refrigerator to a Water-Heater and a Heating Floor}

We will begin by determining the intervals of real operating time of the refrigerator and the heat transfer between the condenser and water or floor to be heated.

\subsection{Preliminary Study of Dimensioning}

The tracing of the histogram of Figure 4 allows to know 


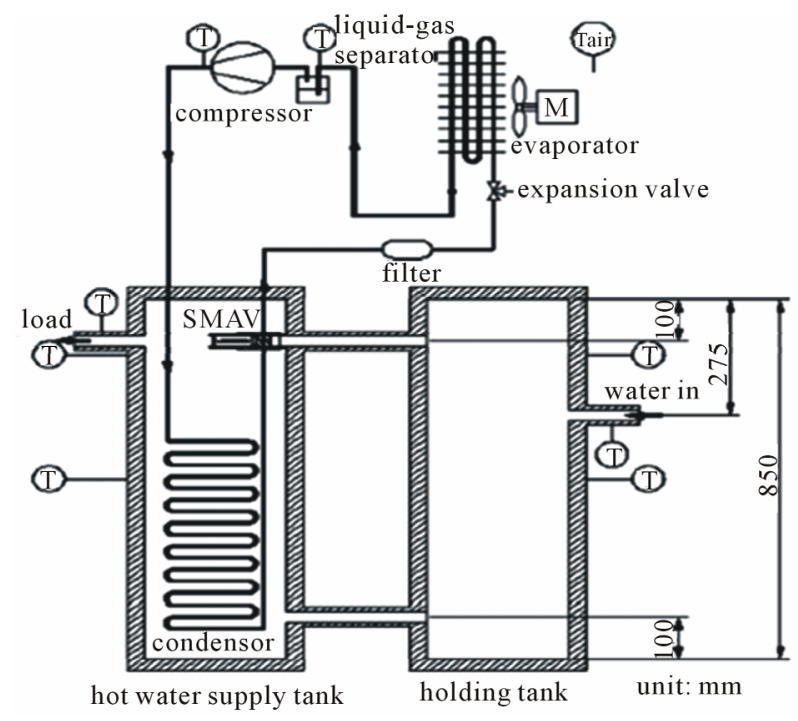

Figure 1. Water heating by heat pump.

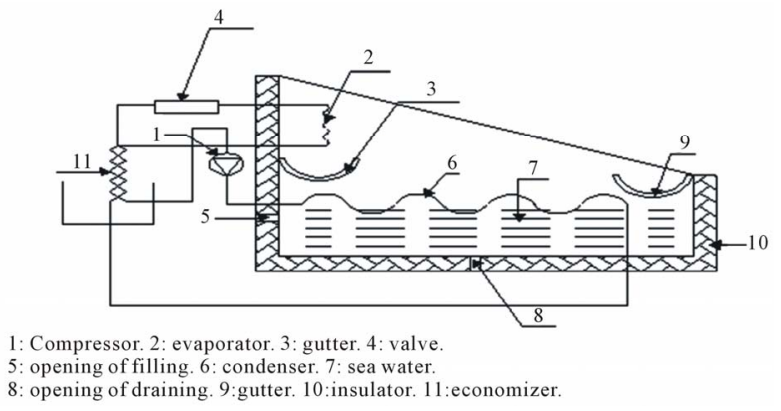

Figure 2. Solar distiller provided with heat pump.

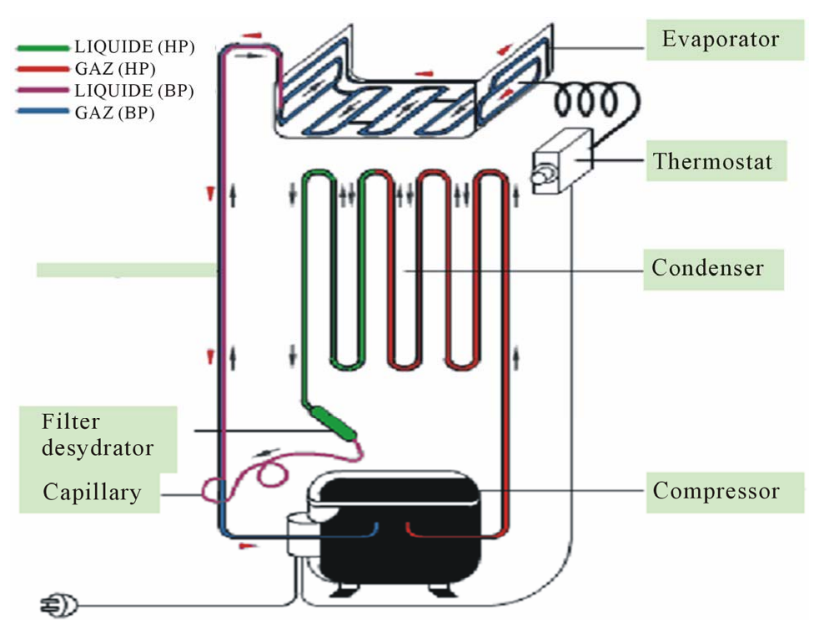

Figure 3. Refrigerator operation cycle [2].

the operating time of refrigerator' compressor during 24 hours. The operating time varies from one moment to another as required by the refrigerator.

Operation of a refrigerator during 24 hours.

$$
\sum \mathrm{t}_{\text {compressor }}=9 \mathrm{~h} 43 \mathrm{~min} / \text { day }
$$

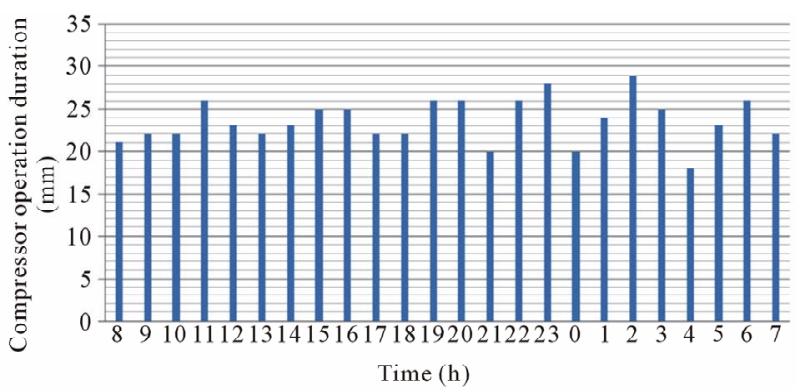

Figure 4. Time operation life of a refrigerator lasting $24 \mathrm{~h}$. Compressor power of $140 \mathrm{~W}$ and using R13a freon. Room temperature $=19^{\circ} \mathrm{C}$ (Tozeur, Tunisia, on March 20, 2009).

\subsection{Theoretical Study of a Refrigerator to a Water-Heater Coupling}

The energy yielded by the condenser is transferred to water to be heated. However, when water heats in the storage tank, thermals loss will appear (coefficient $\mathrm{U}=$ $\left.4.92 \mathrm{~W} /{ }^{\circ} \mathrm{C}\right)$.

\subsubsection{Modeling}

The refrigerating machine can be modeled by considering energies on the level of the compressor, the condenser and the evaporator, as follows:

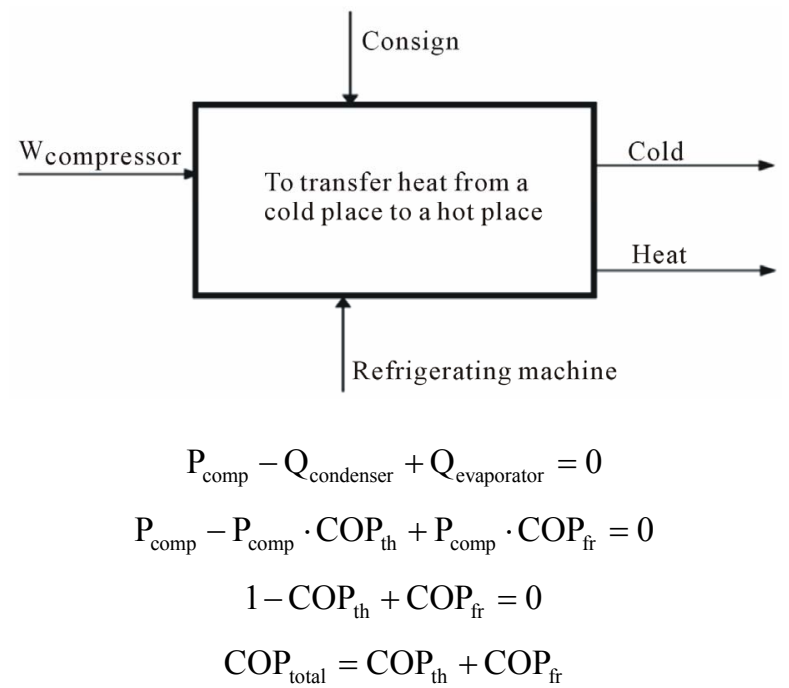

The total COP can thus reach raised values, which confers on our system a great energetic effectiveness, because, usually the refrigerating machine is used either like refrigerator to produce the cold, or like heat pump to heat.

\subsubsection{Thermal Transfer}

For the coupling of a refrigerator to a water cumulus study, we make the calculation of the water mass which can be heated with different temperatures. The efficiency is then evaluated.

It is supposed that the heat yielded by the condenser is 
recovered by water to heat.

$$
\begin{gathered}
\mathrm{Q}_{\text {condenser }}=\mathrm{Q}_{\text {water }} \\
\mathrm{COP} \cdot \mathrm{P}_{\text {comp }} \cdot \mathrm{t} \cdot \eta=\mathrm{M}_{\text {water }} \cdot \mathrm{Cp} \cdot \Delta \mathrm{T}
\end{gathered}
$$

$\Delta \mathrm{T}$ is the water temperature increase from initial to final state.

It is possible to determine the variation of $\Delta \mathrm{T}$ according to time, in the same way for the efficiency.

Determination of heat water storage efficiency

$$
\eta=\mathrm{Q}_{\text {useful }} / \mathrm{Q}_{\mathrm{absorbed}}
$$

With:

$$
\begin{aligned}
\mathrm{Q}_{\text {absorbed }} & =\mathrm{P}_{\text {comp }} \cdot \mathrm{COP} \cdot \mathrm{t} \\
\mathrm{Q}_{\text {useful }} & =\mathrm{Q}_{\text {abs }}-\mathrm{Q}_{\text {loss }} \\
\mathrm{Q}_{\text {loss }} & =\mathrm{U} \cdot \Delta \mathrm{T} \cdot \mathrm{t}
\end{aligned}
$$

$\mathrm{P}_{\text {comp }}$ : Compressor power.

$\mathrm{t}$ : summon operating time of compressor.

$\mathrm{U}$ : thermal loss ratio.

$$
\mathrm{U}=\frac{\rho \cdot \mathrm{Cp} \cdot \mathrm{V}}{\Delta \mathrm{t}} \cdot \ln \left(\frac{\mathrm{T}_{\mathrm{i}}-\mathrm{T}_{\mathrm{am}}}{\mathrm{T}_{\mathrm{f}}-\mathrm{T}_{\mathrm{am}}}\right)
$$

Therefore we have:

$$
\eta=\frac{\mathrm{P}_{\text {comp }} \cdot \mathrm{COP} \cdot \mathrm{t}-\mathrm{U} \cdot \Delta \mathrm{T} \cdot \mathrm{t}}{\mathrm{P}_{\text {comp }} \cdot \mathrm{COP} \cdot \mathrm{t}}
$$

Temperature variation

We replace (4) in (1), then:

$$
\Delta \mathrm{T}=\frac{\mathrm{P}_{\text {comp }} \cdot \mathrm{COP} \cdot \mathrm{t}}{\mathrm{U} \cdot \mathrm{t}+\mathrm{M}_{\text {water }} \cdot \mathrm{Cp}}
$$

Mass of water to heat

Replacing (5) in (4), so:

$$
\mathrm{M}_{\text {water }}=\frac{\mathrm{P}_{\text {comp }} \cdot \mathrm{COP} \cdot \mathrm{t}}{\Delta \mathrm{T} \cdot\left(\frac{\mathrm{Cp}}{\Delta \mathrm{t}} \cdot \ln \left(\frac{\mathrm{T}_{\mathrm{i}}-\mathrm{T}_{\text {amb }}}{\mathrm{T}_{\mathrm{f}}-\mathrm{T}_{\text {amb }}}\right) \cdot \mathrm{t}+\mathrm{Cp}\right)}
$$

The calculation of the water mass to heat, during 24 hours, can be carried out for different water temperature rise.

According to expression (6) we give Table 1.

1) $\Delta T$ variation and efficiency according to time for water capacity of 50 liters which is the experimentally capacity used.

Thermal loss coefficient

With:

$$
\begin{gathered}
\mathrm{Cp}_{\text {water }}=4185 \mathrm{~J} /\left(\mathrm{kg}^{\circ} \mathrm{C}\right) \\
\rho_{\text {water }}=1000 \mathrm{~kg} / \mathrm{m}^{3} \\
\Delta \mathrm{t}=11 \text { hours } ; 18: 00 \rightarrow 5: 00 \\
\mathrm{~V}=0.05 \mathrm{~m}^{3}
\end{gathered}
$$

$$
\begin{gathered}
\mathrm{T}_{\mathrm{i}}=59^{\circ} \mathrm{C} ; \mathrm{T}_{\mathrm{ami}}=26^{\circ} \mathrm{C} \\
\mathrm{T}_{\mathrm{f}}=35^{\circ} \mathrm{C} ; \mathrm{T}_{\mathrm{amf}}=22^{\circ} \mathrm{C} \\
\mathrm{U}=4.92 \mathrm{~W} /{ }^{\circ} \mathrm{C}
\end{gathered}
$$

According to the expressions (2) and (3) we calculated the temperature rise, the efficiency, the useful and absorptive energies, gathered in the following Table 2 and Figure 5.

With:

$$
\mathrm{P}_{\text {comp }}=140 \mathrm{~W} ; \mathrm{COP}=3 ; \mathrm{M}_{\text {water }}=50 \mathrm{Kg}
$$

With time, water warms up by the heat yielded by the condenser; then, the quantity of heat contained in water increases. However, the energetic efficiency decreases following the increase in the losses by convection with the ambient air (Figure 5).

2) Checking length of the condenser immersed in the hot water cumulus

In our case, the flow of the refrigerant (R134a freon) in the condenser immersed in the cumulus is done from top to bottom, i.e. in against current with the circulation of the water to be heated which is done upwards.

Table 1. Value of water mass for different rise in temperature.

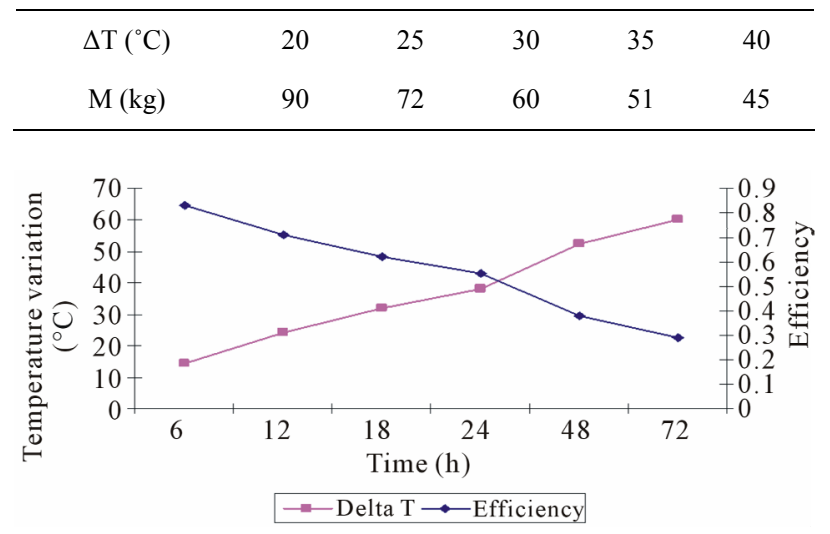

Figure 5. Rise variation in water temperature according to time.

Table 2. Variation of $\Delta \mathrm{T}$ and efficiency according to time.

\begin{tabular}{ccccc}
\hline $\begin{array}{c}\text { Time } \\
\text { (hours) }\end{array}$ & $\Delta \mathrm{T}\left({ }^{\circ} \mathrm{C}\right)$ & efficiency & $\mathrm{Q}_{\text {useful }}(\mathrm{J})$ & $\mathrm{Q}_{\text {abs }}(\mathrm{J})$ \\
\hline 6 & 14.20 & 0.83 & 2972654 & 3565800 \\
12 & 24.35 & 0.71 & 509736 & 7131600 \\
18 & 32 & 0.62 & 6691162 & 10697400 \\
24 & 38 & 0.55 & 7930746 & 14263200 \\
48 & 52.50 & 0.38 & 10986005 & 28526400 \\
72 & 60.22 & 0.29 & 12604349 & 42789600 \\
\hline
\end{tabular}


Therefore the difference in logarithmic average temperature curve will be carried out in an against current cycle (Figure 6).

According to Table 2 of comparison during 12 hours and according to measurements:

- Hot source: (condenser)

$\mathrm{T}_{\mathrm{e}}=62^{\circ} \mathrm{C}$ and $\mathrm{T}_{\mathrm{s}}=43^{\circ} \mathrm{C}$

- Cold source: (water to be heated); with $(\Delta \mathrm{T}=$ $\left.24.35^{\circ} \mathrm{C}\right)$

$\mathrm{t}_{\mathrm{e}}=20^{\circ} \mathrm{C}$ and $\mathrm{t}_{\mathrm{s}}=44.35^{\circ} \mathrm{C}$

- Determination of logarithmic average temperature difference $\Delta \mathrm{TmL}$

The expression of $\Delta \mathrm{TmL}$ is:

$$
\begin{gathered}
\Delta \mathrm{TmL}=\frac{\Delta \mathrm{T} 0-\Delta \mathrm{TL}}{\ln \left(\frac{\Delta \mathrm{T} 0}{\Delta \mathrm{TL}}\right)} \\
\Delta \mathrm{T} 0=\mathrm{Te}-\mathrm{ts}=62-44.35=17.65^{\circ} \mathrm{C} \\
\Delta \mathrm{TL}=\mathrm{Ts}-\mathrm{te}=43-20=23^{\circ} \mathrm{C} \\
\Delta \mathrm{TmL}=20.16^{\circ} \mathrm{C}
\end{gathered}
$$

- Heat exchange coefficient:

The condenser exchanger contains freon which passes from vapor state to liquid state by yielding its heat to water to be heated (Figure 7).

$$
\mathrm{Ui}=\frac{1}{\frac{1}{\mathrm{~h} \text { freon }}+\mathrm{di} \cdot \frac{\ln \ln \left(\frac{\mathrm{de}}{\mathrm{di}}\right)}{2 \cdot \lambda_{\text {copper }}}+\frac{1}{\mathrm{~h}_{\text {water }}}}
$$

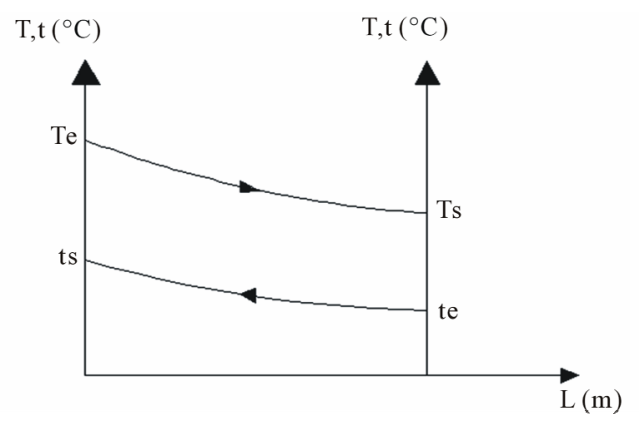

Figure 6. Cycle of against current.

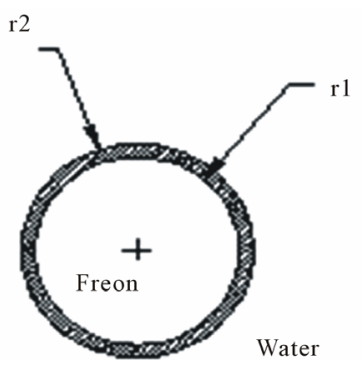

Figure 7. Heat exchanger (water condenser).
With:

$\mathrm{h}$ water $=50 \mathrm{~W} /\left(\mathrm{m}^{2{ }^{\circ}} \mathrm{C}\right) ; \mathrm{h}$ freon $=4200 \mathrm{~W} /\left(\mathrm{m}^{2^{\circ}} \mathrm{C}\right)$;

$\lambda$ copper $=390 \mathrm{~W} /\left(\mathrm{m}^{\circ} \mathrm{C}\right)$

$$
\mathrm{di}=0.004 \mathrm{~m} ; \mathrm{de}=0.006 \mathrm{~m}
$$

Then:

$$
\mathrm{Ui}=50 \mathrm{~W} /\left(\mathrm{m}^{\circ} \mathrm{C}\right)
$$

\subsection{Theoretical Study of the Coupling of a Refrigerator to a Heating Floor}

In this section we will make the study of a refrigerator to a heating floor coupling, and the determination of the temperature variation for each surface for different periods and for different surfaces to be heated.

Calculation is carried out on concrete surfaces height $h$ $=0.1 \mathrm{~m}$.

There is a thermal contact between two bodies thus there is a heat transfer between the two bodies in contact (condenser/concrete).

$$
\begin{aligned}
& \mathrm{Q}_{\text {condenser }}=\mathrm{Q}_{\text {concrete }} \\
& \mathrm{COP} \cdot \mathrm{P}_{\text {comp }} \cdot \mathrm{t} \cdot \eta=\mathrm{M}_{\text {concrete }} \cdot \mathrm{Cp} \cdot \Delta \mathrm{T}
\end{aligned}
$$

$\Delta \mathrm{T}$ : variation between the final and the initial tem- perature of the floor.

- Determination of the temperature variation $\Delta \mathrm{T}$

We have:

$$
\eta=\mathrm{Q}_{\text {useful }} / \mathrm{Q}_{\text {absorbed }}=\mathrm{Q}_{\text {absorbed }}-\mathrm{P}_{\text {loss }} / \mathrm{Q}_{\text {absorbed }}
$$

With:

- $\mathrm{Q}_{\text {absorbed }}=\mathrm{P}_{\text {comp }} \cdot \mathrm{COP} \cdot \mathrm{t}$

- $\mathrm{P}_{\text {loss }}=\mathrm{U} \cdot \mathrm{S} \cdot \Delta \mathrm{T} \cdot \mathrm{t}$

- $\mathrm{Q}_{\text {useful }}=\mathrm{Q}_{\text {absorbed }}-\mathrm{P}_{\text {loss }}$

The initial temperature is equal to the ambient temperature.

Thus:

$$
\eta=\frac{\mathrm{P}_{\text {comp }} \cdot \mathrm{COP} \cdot \mathrm{t}-\mathrm{U} \cdot \mathrm{S} \cdot \Delta \mathrm{T} \cdot \mathrm{t}}{\mathrm{P}_{\text {comp }} \cdot \mathrm{COP} \cdot \mathrm{t}}
$$

We replace (10) in (11):

$$
\Delta \mathrm{T}=\frac{\mathrm{P}_{\text {comp }} \cdot \mathrm{COP} \cdot \mathrm{t}}{\mathrm{U} \cdot \mathrm{S} \cdot \mathrm{t}+\mathrm{M}_{\text {concrete }} \cdot \mathrm{Cp}}
$$

With:

$$
\mathrm{M}_{\text {concrete }}=\rho \cdot \mathrm{S} \cdot \mathrm{H}
$$

Finally:

$$
\Delta \mathrm{T}=\frac{\mathrm{P}_{\text {comp }} \cdot \mathrm{COP} \cdot \mathrm{t}}{\mathrm{S} \cdot(\rho \cdot \mathrm{H} \cdot \mathrm{Cp}+\mathrm{U} \cdot \mathrm{t})}
$$

Table 3 and Figure 8 indicate the variations of $\Delta \mathrm{T}$ according to time and the floor surface. 
The reached temperature on the floor level is a function of the exchange surface with the condenser; in fact also with the compressor power.

In practice, a prototype of heating sand floor of surface $\mathrm{S}=0.43 \mathrm{~m}^{2}$ was produced and in which a condenser of 6 $\mathrm{m}$ length is immersed there.

\section{Experimental Study}

First, we make the water cumulus then its coupling with the refrigerator and the heating floor.

\subsection{Water Cumulus Realization}

We have a cylindrical tank in plastic, diameter $0.38 \mathrm{~m}$ and height $0.48 \mathrm{~m}$, which is isolated by five $\mathrm{cm}$ glass woo. The unit is then covered by a thin stainless steel jacket (Figure 9).

\subsection{Coupling between the Refrigerator and the Water Cumulus}

We replaced the refrigerator condenser by a copper spiral serpentine placed in the water cumulus, thus the freon condensation will allow to yield the latent heat to water and thus to constitute a hot water storage (Figures 10, 11).

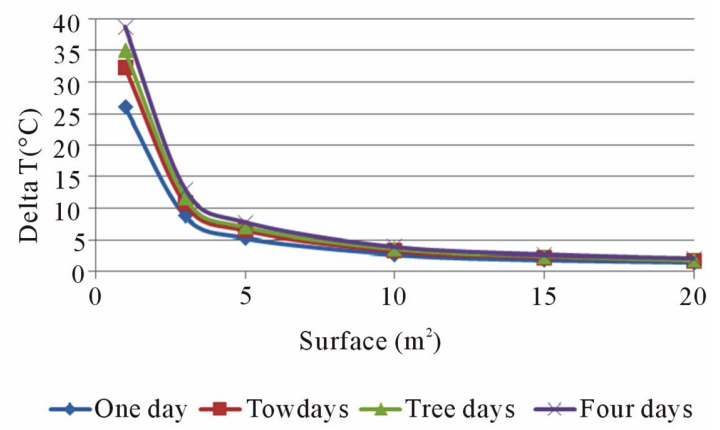

Figure 8. Floor temperature rise according to surface and a number of day.

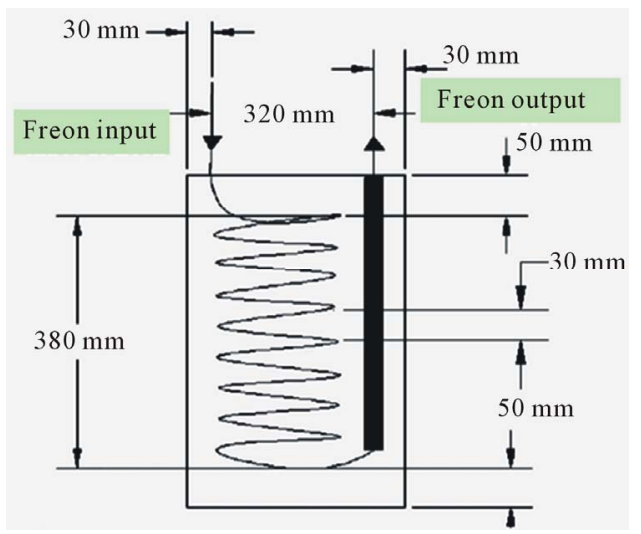

Figure 9. Dimensions of the copper condenser immersed in the water cumulus.
Table 3. Variation of $\Delta \mathrm{T}$ according to time and of surface.

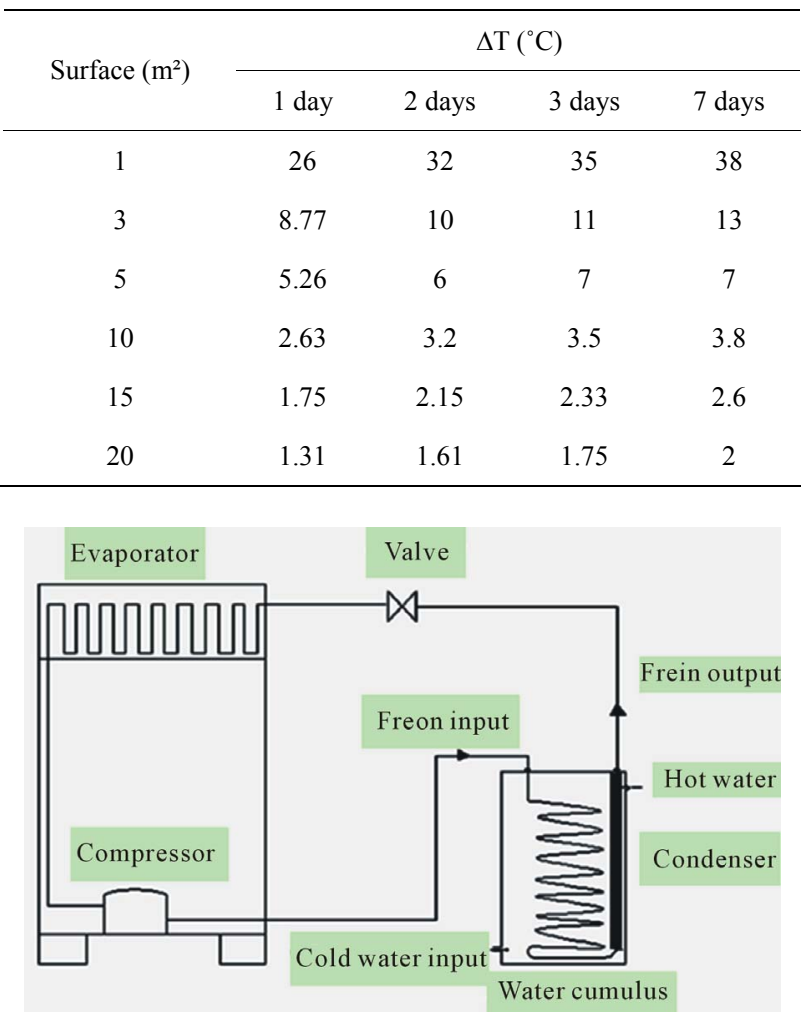

Figure 10. Refrigerating circuit binding the refrigerator and the water-heater.

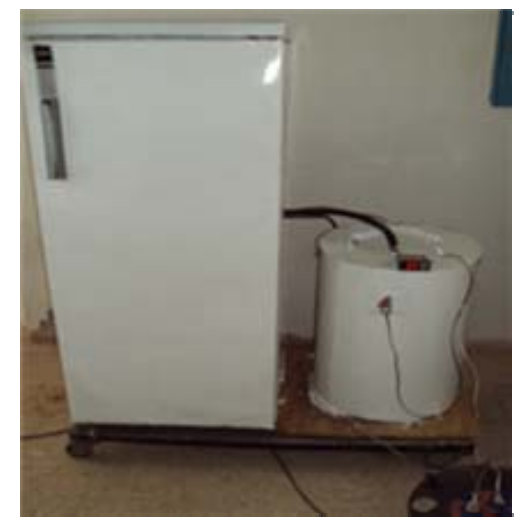

Figure 11. Coupling of the refrigerator to a water-heater photograph.

\subsection{Heating Floor Realization}

The goal for the moment is to construct a transportable prototype. Thus the floor is carried out by some sand filling of a wood box of dimensions $0.66 \mathrm{~m} \times 0.66 \mathrm{~m}$, that is to say a surface of $0.43 \mathrm{~m}^{2}$. As the selected height is $0.1 \mathrm{~m}$, then the sand mass is:

$$
\mathrm{M}=\rho \cdot \mathrm{S} \cdot \mathrm{H}=66.6 \mathrm{Kg}
$$

The condenser of refrigerator is then placed in the wood box before filling this latter by dry sand (Figure 12). 


\subsection{Refrigerator and Heating Floor Coupling}

For this system, the refrigerator' condenser is placed in the box filled with sand, thus, the foran condensation does not directly heat the air but the sand, and stores its heat in the heating floor (Figures 13-15).

Notice:

It is also possible to couple the water cumulus and the floor heating with only one refrigerator using an electromagnetic sluice gate which makes it possible to ensure the commutation of the refrigerating circuit of the refrigerator either towards the hot water cumulus, or towards

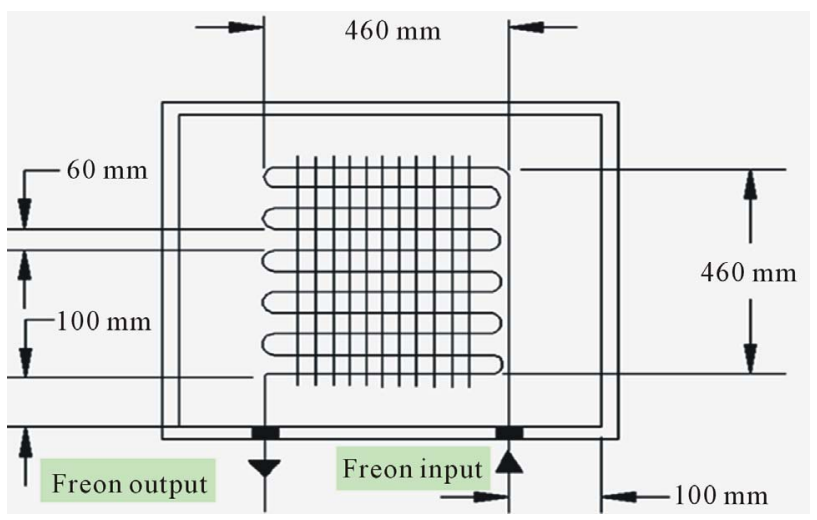

Figure 12. Dimensions of the refrigerator condenser immersed in the sand floor.

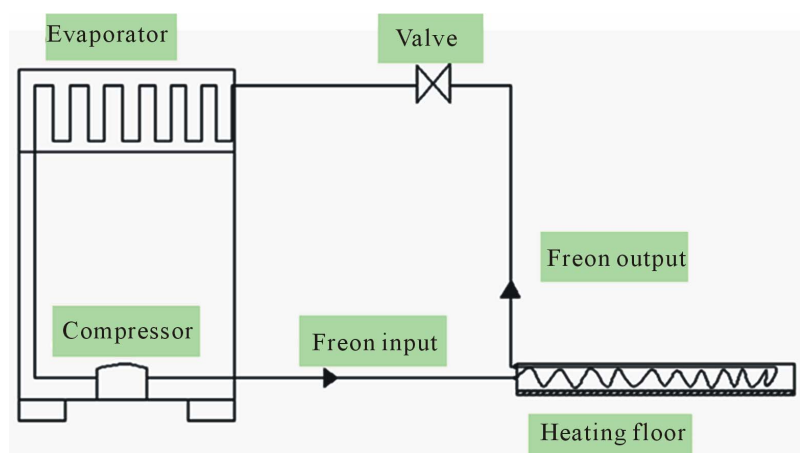

Figure 13. Installation circuit of refrigerator/heating floor coupling.

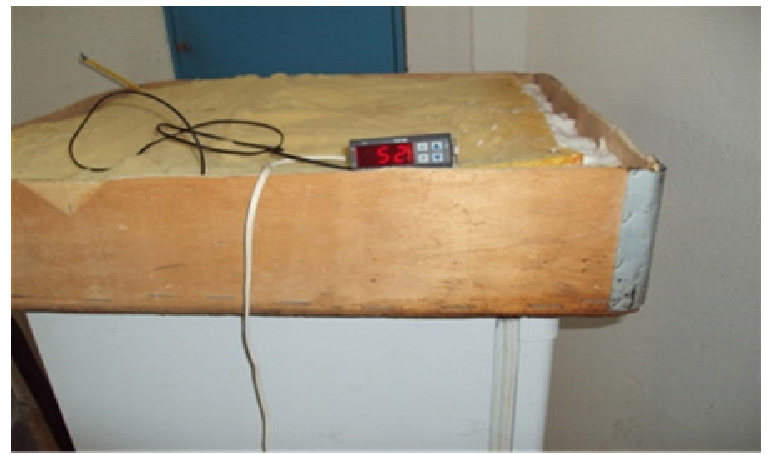

Figure 14. Small-scale model of the heating sand floor photographs.

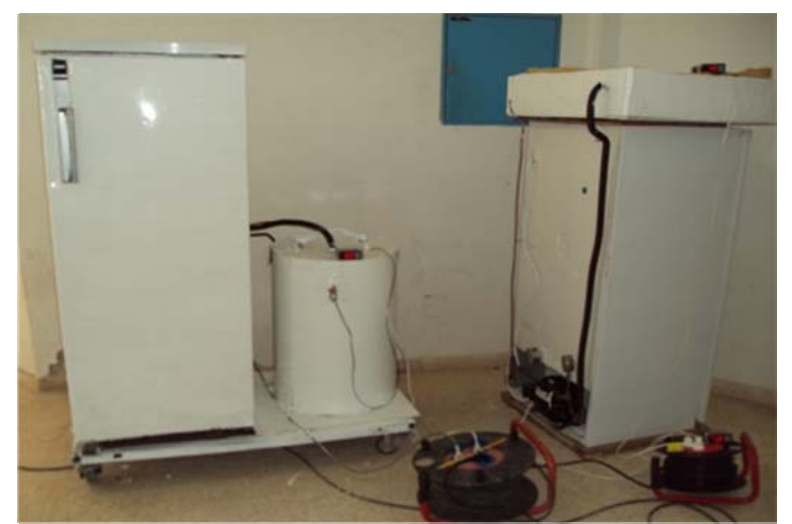

Figure 15. Photographs of the two refrigerators: One coupled with the water-heater, the other with the heating floor.

the heating floor.

It is also to be noted that the floor can be heated in a "conventional" way by the water from big tank storage, heated by the condenser of fridges which has restaurants and hotels or refrigeration rooms of foods conservation, or other.

\subsection{Experimental Results}

The experiments make it possible to bind the refrigerator to the system to be heated (water and heating floor) and to record the heating, refrigeration and ambient temperatures.

\subsubsection{Evolution of Water-Heater Temperature}

We study here the coupling of the refrigerator to a water heating cumulus.

1) First test

Figure 16 shows that in the morning, with the refrigerator starting, the rise in the storage water temperature is slower than that of the interior of refrigerator (approximately $8 \mathrm{~h} 30$ against $2 \mathrm{~h}$ ), this is because of the difference in heat mass capacity between water and air (4185 against $1000 \mathrm{~J} / \mathrm{kg}^{\circ} \mathrm{C}$ ).

With an ambient temperature of $26^{\circ} \mathrm{C}$, water temperature reached is $59^{\circ} \mathrm{C}$, that is to say a rise in water temperature of $33^{\circ} \mathrm{C}$.

2) Second test

At the end of the one day operation, the refrigerator is voluntarily stopped for reasons of night safety. The following day at $5 \mathrm{am}$, the tests began again by the refrigerator restarting. The water temperature was $35^{\circ} \mathrm{C}$, that is to say $15^{\circ} \mathrm{C}$ higher than for the previous day; what shows that the cumulus stores well heat thanks to its heat insulation with glass wool.

According to Figure 17, the temperature increases in the same manner than the first test, it reaches the permanent mode $\left(59^{\circ} \mathrm{C}\right)$ at the end of eight hours. A racking of ten liters hot water was carried out from the cumulus, 
followed by a filling of the same cold water capacity. Quickly the water temperature decreased up to $45^{\circ} \mathrm{C}$ then it increased gradually to reach again the permanent mode at the end of four hours, against five hours and half for the preceding heating and the same variation in temperature. This is to show that hot water can be used several times per day.

\subsubsection{Heating Floor Temperature Evolution}

Is studied here the coupling of the refrigerator to a heated floor consisting of a layer of sand.

For the input/output curves of temperatures in the floor (Figure 18), we distinguish three zones: Zones 1 and 2 without insulation and zone 3 with insulation.

- Zone $1[5 \mathrm{~h}-10 \mathrm{~h}]$ : Fast rise in floor temperatures according to time.

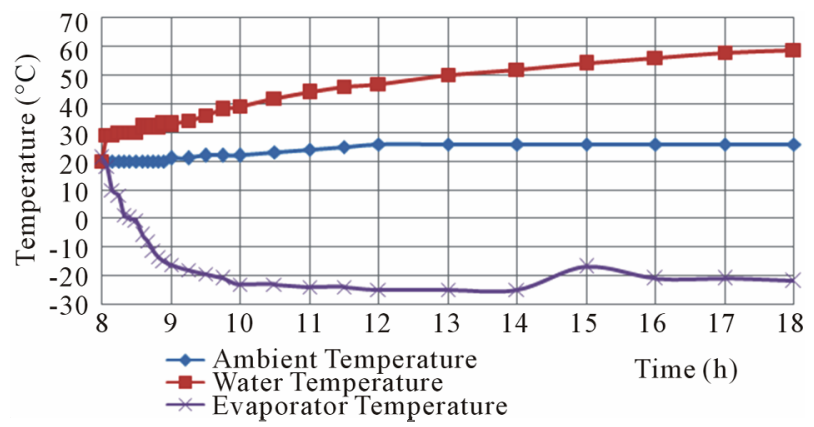

Figure 16. Variation of the temperatures according to time. Water heating case.

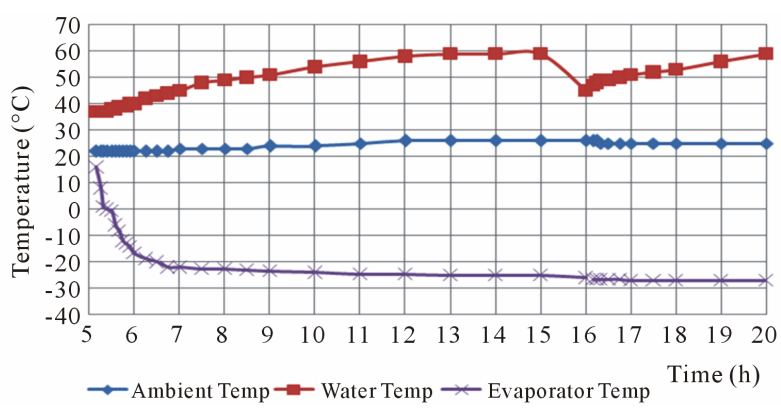

Figure 17. Variation of water, evaporator and ambient temperatures before and after draining of $\mathbf{1 0}$ liters water.

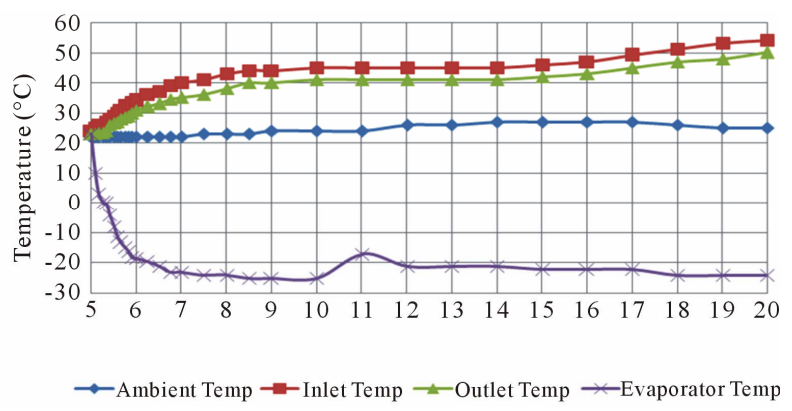

Figure 18. Temperature variation according to time. Heating floor case.
- Zone $2[10 \mathrm{~h}-14 \mathrm{~h}]$ : The temperatures reach their maximum values (permanent mode with $45^{\circ} \mathrm{C}$ to $\left.43^{\circ} \mathrm{C}\right)$.

- Zone $3[14 \mathrm{~h}-20 \mathrm{~h}]$ : Floor temperatures rise compared to Zone 2 up to $54^{\circ} \mathrm{C} / 52^{\circ} \mathrm{C}$ thanks to the heat insuslation.

If the heating floor is insulated, then the heat quantity stored in sand increases in a significant way.

\section{Conclusions}

By this project, we tried to widen the use of a refrigerating system for the water heating, spaces or buildings, and this by the exploitation of the energy previously rejected by the condenser. With this manner the refrigerator can contribute to heat water and/or floor-heating; while keeping its principal function to cool.

The temperatures reached respectively, by water and floor, are approximately $60^{\circ} \mathrm{C}$ and $50^{\circ} \mathrm{C}$, without modifying the temperature of the evaporator, which is at approximately $-20^{\circ} \mathrm{C}$.

The elimination of the grid of the usual condenser located at the back of the refrigerator creates an advantage: to avoid its heating and consequently up time of the compressor and thus its electric consumption.

Finally, the results obtained as well theoretically as in experiments show clearly that the heat withdraws coming from the condenser immersed in water or sand, is a reliable source of heat, being able to be useful at least for pre-heating of water or room. The recovered heat enters in the négawatts production concept.

\section{REFERENCES}

[1] B. Slama and R. Thermodynamic, "Heat Water by the Condenser of Refrigerator," International Symposium on Convective Heat and Mass Transfer in Sustainable Energy, Hammamet, April 26 to May 1, 2009.

[2] S. R. Ben, "Water-Heater Coupled with the Refrigerator to Develop the Heat of the Condenser," International Renewable Energy Congress IREC, Sousse, 5-7 November 2009, pp. 12-18.

[3] S. R. Ben, "Thermodynamic Heat Water by the Condenser of Refrigerator," $1^{\text {ère }}$ Conférence Maghrébine Sur les Matériaux et l'Energie, Gafsa, 26-28 Mai 2010.

[4] S. R. Ben, "Coupling of a Refrigerator to a Water Heater and Heating Floor," GRETH Heat Set, Opatija, 18-22 October 2010.

[5] S. R. Ben, "Production de Negawatts Par Couplage d'Un Refrigerateur à Un Chauffe-Eau," Congres de la Société Française de Thermique: Energie Solaire et Thermique, Perpignan, 24-27 Mai 2011.

[6] S. R. Ben, "Water Heating by Recovery of Heat Released by the Refrigerator," 23rd IIR International Congress of Refrigeration, Praha, 21-26 August 2011.

[7] G. Grazzini and R. Rinaldi, "Thermodynamic Optimal 
Design of Heat Exchangers for an Irreversible Refrigerator," International Journal of Thermal Sciences, Vol. 40, No. 2, 2001, pp. 173-180.

[8] V. Skrivan, "L'Utilisation de La Chaleur de Condensation des Groupes Frigorifiques de Moyenne Puissance Pour le Chauffage de L'Eau," Revue Internationale du Froid, 1984, pp. 14-20.

[9] B. J. Huang, J. H. Wang, J. H. Wu and P. E. Yang, "A Fast Response Heat Pump Water Heater Using Thermostat Made from Shape Memory Alloy," Applied Thermal Engineering, Vol. 29, No. 1, 2009, pp. 56-63.

[10] J. Ji, K. Liu, T.-T. Chow, G. Pei, W. He and H. He, "Performance Analysis of a Photovoltaic Heat Pump," Applied Energy, Vol. 85, 2008, pp. 680-693.

[11] M. N. A. Hawlader and K. A. Jahangeer, "Solar Heat Pump Drying and Water Heating in the Tropics," Solar Energy, Vol. 80, 2006, pp. 492-499.

[12] M. N. A. Hawlader, S. K. Chou, K. A. Jahangeer, S. M. A. Rahman and L. K. W. Eugene, "Solar-Assisted HeatPump Dryer and Water Heater," Applied Energy, Vol. 74, 2003, pp. 185-193.

[13] Y. W. Li, R. Z. Wang, J. Y. Wu and Y. X. Xu, "Experimental Performance Analysis on a Direct Expansion Solar-Assisted Heat Pump Water Heater," Applied Thermal Engineering, Vol. 27, 2007, pp. 2858-2868.

[14] J. P. Chyng, C. P. Lee and B. J. Huang, "Performance Analysis of a Solar-Assisted Heat Pump Water Heater," Solar Energy, Vol. 74, 2003, pp. 33-44.

[15] B. J. Huang and J. P. Chyng, "Performance Characteristics of Integral Type Solar Assisted Heat Pump," Solar
Energy, Vol. 71, 2001, pp. 403-414.

[16] B. J. Huang, J. P. Lee and J. P. Chyng, "Heat-Pipe Enhanced Solar-Assisted Heat Pump Water Heater," Solar Energy, Vol. 78, 2005, pp. 375-381.

[17] S. R. Ben and S. Gabsi, "Distillateur Solaire Activé Par Une Pompe à Chaleur à Compression," Journées Tunisiennes des Ecoulements et des Transferts JTET, Monastir, 19-21 Mars 2006.

[18] S. R. Ben and S. Gabsi, "Conception et Expérimentation d'un Distillateur d'Eau de Mer Solaire/Pompe à Chaleur," Premières Journées Tunisiennes sur le Traitement et le Dessalement de l'Eau JNTDE, Hammamet, 4-7 Novembre 2006.

[19] S. R. Ben, K. Hidouri and S. Gabsi, "Study of An Hybrid Water Solar Distiller Coupled with Heat Pump," GREITH Heat Set 2007, Chambery, 18-20 Avril 2007, pp. 677-684.

[20] S. R. Ben, K. Hidouri and S. Gabsi, "Performance of an Hybrid Sea Water Distiller Solar/Heat Pump," ICAMEM, Hammamet, 19 December 2006.

[21] S. R. Ben and S. Gabsi, "Design and Experimentation of a Solar Sea Water Distiller/Heat Pump," TIWATMED, Djerba, 24-26 Mai 2007.

[22] S. R. Ben, K. Hidouri and S. Gabsi, "Distillateur Solaire Hybride à Pompe à Chaleur à Compression," $1^{\text {er }}$ Colloque Maghrebin sur le Traitement et le Dessalement des Eaux CMTDE, Hammamet, 7-10 Décembre 2007.

[23] K. Hidouri, S. R. Ben and S. Gabsi, "Hybrid Solar Still by Heat Pump Compression," Desalination, Vol. 250, 2010, pp. 444-449. 


\section{Nomenclature}

\begin{tabular}{|c|c|}
\hline $\mathrm{COP}$ & coefficient of performance \\
\hline $\mathrm{Cp}$ & heat mass $\left(\mathrm{J} \cdot \mathrm{kg}^{-1 \circ} \mathrm{C}^{-1}\right)$ \\
\hline $\mathrm{h}$ & heat exchange cefficient $\left(\mathrm{Wm}^{-2} \cdot \mathrm{K}^{-1}\right)$ \\
\hline M & Mass $(\mathrm{kg})$ \\
\hline $\mathrm{P}_{\text {comp }}$ & power of the compressor (W) \\
\hline Q & Heat quantity $(\mathrm{J})$ \\
\hline S & surface $\left(m^{2}\right)$ \\
\hline $\mathrm{t}$ & time (h) \\
\hline $\mathrm{U}$ & convection losses coefficient $\left(\mathrm{Wm}^{-2} \cdot \mathrm{K}^{-1}\right)$ \\
\hline $\mathrm{S}$ & surface $\left(\mathrm{m}^{2}\right)$ \\
\hline $\mathrm{T}$ & Temperature $\left({ }^{\circ} \mathrm{C}\right)$ \\
\hline$\Delta \mathrm{T}$ & Temperature variation $\left({ }^{\circ} \mathrm{C}\right)$ \\
\hline$\Delta \mathrm{t}$ & time variation $(\mathrm{s})$ \\
\hline$\eta$ & efficiency \\
\hline$\rho$ & density $\left(\mathrm{kg} / \mathrm{m}^{3}\right)$ \\
\hline$\lambda$ & conductivity transfer coefficient $\left(\mathrm{Wm}^{-1} \cdot \mathrm{K}^{-1}\right)$ \\
\hline \multicolumn{2}{|l|}{ Signes } \\
\hline $\mathrm{amb}$ & ambient \\
\hline $\mathrm{i}$ & initial \\
\hline $\mathrm{f}$ & final \\
\hline th & thermal \\
\hline fr & refrigerator \\
\hline
\end{tabular}

